\title{
TEACHERS' PREPAREDNESS FOR ACTIVITY IN THE CONTEXT OF INCLUSIVE PRACTICE
}

\author{
Kirillova, $E^{1}$, Nabiullina, $\mathrm{R}^{2}$ and Faizrakhmanova, $\mathrm{A}^{3}$ \\ 1, 2,3 Kazan (Volga region) Federal University Institute of Psychology and Education
}

\begin{abstract}
The arrangement of available and quality education for individuals with special educational needs is a necessary condition for such people's successful socialization in society. The development of inclusion in education is one of the priority directions of public policy in Russia nowadays. However, there are various barriers that hinder inclusive education implementation. One of such barriers is unavailability of teaching staff to work in new conditions. The authors carried out a survey of teachers to reveal difficulties they experience in the course of entering an inclusive environment. Such obstacles as teachers' insufficient competence in the sphere of psychophysiological features of individuals with special educational needs; lack of technologies aimed to train individuals with special educational needs; psychological unavailability have been revealed. Main professional difficulties that teachers meet working at all stages of training (preschool, school, and higher school) connected with emotional rejection and knowledge of peculiarities of individuals with special educational needs are described. The results of the survey testify to the fact that teachers have embraced ideas and principles of inclusive education in Russia. The obtained data prove the necessity of teachers' vocational and psychological training for an appropriate work in the conditions of inclusive education.
\end{abstract}

Keywords: Inclusive education, teachers, individuals with special needs, learners with special educational needs, barriers, professional difficulties

\section{INTRODUCTION}

Inclusive education of persons with disabilities becomes one of the main tendencies of the modern educational practice development.

In connection with the implementation of inclusive education further requests for the organization of educational activities are forthcoming. There appears a need for modification and transformation of the existing bases of professional work of a teacher. Ensuring the optimal conditions for the development and socialization of persons with disabilities becomes dominant. Therefore, the problem of teachers willingness to work in the new environment is rather sharply raised (Rieser (2013), Naraian (2013)).

The provosions and conceptual foundations of the Education Act dictate the need for teachers to master special competence, ensuring the quality of education of different categories of persons, in particular those with special educational needs. The new conditions of teacher's work require the formation of a new professional position of the teacher allowing them to implement effectively educational programs in modern conditions (Alekhina (2013), Nigmatov (2013)).

It becomes necessary to further train the teachers with the purpose of giving them knowledge of the psychophysiological peculiarities of invalids and persons with disabilities, the specifics of reception and transmission of educational information, the use of special technical means of education, taking into account different nosology. Education personnel need to be aware of the psychological and physiological characteristics of invalid students and those with disabilities, and take them into account in the organization of the educational process (Akhmetzyanova (2014) Ilyina (2014)).

The work of a teacher in the conditions of inclusive education is diverse in content and function. Hence, there is a need for teachers to master a variety of

Corresponding Author Email: kirillova16102009@mail.ru 
professional skills: gnostic, structural, communicative, organizational and special.

\section{MATERIALS AND METHODS}

Given the current state of education and introduction of inclusive practice it is important to study the willingness of teachers to work in new conditions, the level of their professional competence and psychological training.

In order to determine willingness of teachers, their attitude towards inclusion, finding flaws in their training and other difficulties associated with organization of educational activities of children in inclusive education they surveyed kindergarten teachers, school teachers and university professors.

The survey involved 60 teachers, male and female, aged from 25 to 65 years, who were offered to answer anonymously in a free form the specially developed questions.

The questionnaire included 15 questions. All the questions were divided into four groups. The first group contained general information: age, gender, type of educational institutions (preschool, school, higher education).

The second group of questions was aimed at identifying the attitude of teachers to inclusive education, to persons with disabilities, to the phenomenon of disability. Teachers were offered not only to answer the questions, but also to explain their point of view: How do you feel about inclusive education? Why? Would you like to work in a group with children with disabilities? Why? Would you be able to work in a group with children with disabilities? Why?

The third group included questions aimed at finding out what qualities, knowledge and skills should a teacher, working in conditions of inclusive education have: What professional qualities should have a teacher, working in conditions of inclusive education? What, in your opinion, does a teacher need to work in an inclusive group? What technologies, methods of work, knowledge, skills, must possess a teacher of inclusive education? What competence should a teacher, working in conditions of inclusive practice form?
The fourth group of questions was aimed at identifying the professional difficulties of teachers and failings (barriers) in the organization of educational activities in the inclusive educational institutions. To do this, the following questions were asked: What disadvantages in your professional training can you identify? What are they related to? What does a modern teacher need to work effectively in the conditions of inclusive education? What needs special attention in training today's teachers to work in the conditions of inclusive education?

Thus, the survey was of complex character, as it allowed revealing various aspects of professional willingness of teachers to work in conditions of inclusive practices.

\section{RESULTS}

Following the survey of teaching staff of pre-school, school and higher education the results were as follows: the majority of teachers $(55 \%)$ have a positive attitude towards inclusion, considering the need for joint training of healthy children and children with disabilities in one group of educational institution. They believe that inclusive education promotes social adaptation of children with disabilities in society, the development and formation of moral qualities in healthy students and teachers interacting with people who have special educational needs. Besides, inclusion prevents discrimination on various characteristics and the division of society into classes.

$30 \%$ of mentors, educators and teachers defined their attitude as neutral, explaining it by the fact that they have not formed a unified attitude towards inclusion, as inclusive education has both positive and negative aspects.

$15 \%$ of teachers expressed a negative attitude towards inclusive education, explaining their response by the fact that children with developmental disabilities need to be trained in special (correctional) educational institutions with special educational environment, where teachers of a narrow specialization, focused on specific developmental disorder work. In their opinion, even the most competent general education teacher will not render that assistance to children with disabilities which they received in a special institution. 
Following the study results the attitude of teachers to children with disabilities, to the phenomenon of disability showed that $45 \%$ of teachers treat children with developmental disabilities positively, with understanding, compassion and kindness. $30 \%$ of teachers find it difficult to answer this question, as a determining factor for them is a kind of disease. Teachers could accept children with visual impairment, hearing loss, disorders of musculoskeletal system or speech, but not those with intellectual disabilities and behavioral problems, as well as with some medical conditions such as HIV infection. $25 \%$ of teachers experience inner fear at the sight of children with highly visible external defects (cerebral palsy, facial pathology).

The study of the relationship of teaching staff to the educational process in the conditions of inclusion showed that $60 \%$ of teachers are not ready to implement their professional activities in the given conditions, explaining this by the lack of materialtechnical and methodical equipment, specific knowledge, skills, experience, practice, psychological unpreparedness. $30 \%$ of educators, teachers, and professors are willing to try themselves as a teacher of inclusive education, to enrich the educational experience, improve their professional skills, considering this trend as new and interesting. $10 \%$ of educators and teachers have neutral, somewhat passive attitude to the educational process in an inclusive group, explaining that if they have to teach children with developmental disabilities, they will not refuse.

In the analysis of the following group of responses to the questions aimed at identifying the necessary knowledge, skills, teachers' core competencies for inclusive education the following knowledge and skills have been allocated: basic knowledge of general and correctional pedagogy, general and special psychology, defectology, general, special and inclusive education, the first aid rendering; the laws of development of children in health and disease, medical diagnoses, techniques and methods of work with different children; technology of training for various groups of children; laws and legal acts.

Skills: to establish contact with others; direct attention in the learning process at any student; to adapt the training material in accordance with the educational needs of children; combine various techniques and forms of education; distribute the learning process time; choose an individual approach to each child; interact with colleagues, parents of pupils; use the teachers' experience of colleagues; to maintain a good atmosphere in the group, equal treatment for all children, to prevent all forms of discrimination; manage their emotional state.

Experience: possession of educational material; modern technologies of teaching healthy children and those with developmental disabilities; methods and techniques of teaching healthy children and children with developmental disabilities; first aid rendering skills; skills to organize the educational process in an inclusive group; skills of work with special equipment.

Among the professional qualities important for inclusive education, teachers allocated the following: the capacity for self-development and selfimprovement, love for children and for profession, endurance, perseverance, creativity, sociability and humanity.

Analysis of the fourth group of questions designed to identify some barriers in work of teachers in inclusive practice conditions, showed that $65 \%$ of educators, teachers and professors as the main difficulty singled out educational barrier associated with their lack of necessary training to work in an inclusive institution. $25 \%$ of teachers associate their professional problems with psychological barrier (psychological unwillingness to work in the conditions of inclusive practice, the microclimate in a group or a class, fear of negative peer's attitude to a disabled child). $10 \%$ of educators, teachers and professors believe that the main difficulty is material and technical barriers related to the lack of necessary special and methodological equipment in modern educational institutions.

Thus, the study of teachers' willingness to work in conditions of inclusive practice has shown that the teaching staff is not yet ready to implement the ideas and principles of inclusive education in secondary schools. Teachers have different attitudes to inclusion and some of its aspects. This allows us to talk about the ambiguity and heterogeneity of the education community attitude to the given process. Teachers 
accept inclusion, children with HIA, but at the same time experience an inner fear, discomfort and difficulty in dealing with them. Teachers are willing to improve the missing knowledge and experience as well as professional skills, but worry about the lack of material and technical, as well as methodological support of educational institutions, the relationships in the children's group.

Most of the teaching staff, accepting an inclusive education system, are not psychologically prepared to work in new conditions. Therefore, in the foreground there is a problem to increase motivation, self-esteem of teachers, to overcome internal and external barriers, to relieve an emotional stress, what can be achieved in the course of psychological training, by inclusion in the practical activities of children with HIA, by better understanding of the specifics of an inclusive and special education .

\section{DISCUSSIONS}

The importance of the problem of teachers' willingness to teach persons with disabilities, including an inclusive education, is noted in the works of Alekhinea S.V., Alekseeva M.N., Malofeeva N.N., Denisova O.A., Akhmetzyanova A.I. ., Hitryuk V.V., Hoffman E.M., Rieser R., Pijl, S.J., Loreman, T., Armstrong, F., Ainscow, M. et al (Alekhinea \& Alekseeva (2011), Malofeyev (2012) Denisova (2012), Akhmetzyanova (2014), Hitryuk (2013), Hoffman (2011), Rieser (2013), Pijl (2010), Loreman (2010), Armstrong (2003), Ainscow (2002)).

Teacher's professional willingness acquires a special role.

V.A. Slastenin considered professional willingness as a set of the interconnected and interdependent components (goal-motivational, informativeoperational, emotional-determined and evaluative) to ensure success in the implementation of professionally significant functions (Slastenin (2002)). In the works of Adolf V.A., Ilyina N.F., Stepanova I.Y. willingness for pedagogical activity is treated as a unity of theoretical and practical preparedness, determining the potential of a teacher (Stepanova \& Adolf (2009), Ilyina (2014)).
Analyzing the concept of "professional willingness" in the scientific literature, Koreneva E.N. and Kireev M.N. note that various authors reveal it as a systemic characteristic of the social activity of the individual, integrative indicator of his training level and professional skills. Professional willingness is viewed as an integral personal formation, characterized by a combination of external and internal motivations of individuals to implement their professional knowledge and skills in the modern socio-cultural sphere; by a high level of the acquired general professional competence, as well as by developed reflexion (Korenev \& Kireev (2012)).

Hitryuk V.V. defines the concept of "inclusive willingness" (willingness to work in the conditions of inclusive education) as a complex integral subjective quality of the personality of a teacher, based on a set of academic, professional, social and personal competencies, and determining the effectiveness of vocational and educational activities. At that the academic competence is treated as the knowledge of the methodology and terminology in a particular area of knowledge, as the understanding of the operating in it systemic interrelations, the ability to use them in solving practical problems. Professional competence is understood as willingness and ability to act expediently in accordance with the requirements of the real teaching situation. The socio-personal competences imply a set of competencies related to a man himself as an individual, to the individual's interaction with other people, group and society (Hitryuk (2012)).

Thus, the problem of professional competence of a teacher, especially a teacher of inclusive education, now is relevant and attracts the interest of many scientists and researchers.

\section{CONCLUSION}

Inclusive education is impossible to organize in itself. This process is associated with changes on the level of values and moral (Kirillov (2015), Nabiullina (2015)). The problems of the organization of inclusive education in modern education are linked primarily to the fact that the kindergarten, school, higher school as social institutions are focused on students, capable of moving at the pace specified by the standard program, for whom typical methods of 
pedagogical work are sufficient (Gordon (2014) ). On the one hand, the "mass education with its conservative concept in the form of a relatively homogeneous in success learning groups (classes), with the motivation of studying on the basis of regulatory assessment and interpersonal comparison, creates in the reality significant difficulties to implement the idea of inclusive education" (Alekhina \& Alekseeva \& Agafonova, (2011), Hornby (2015)). On the other hand, the new federal state educational standards specify the requirements for the results of the students, including "willingness to listen to the interlocutor and have a dialogue; willingness to accept the possibility of existence of different points of view and the right for everyone to have his own point of view; willingness to express their opinions and argue their point of view and assessment of events" (Akhmetzyanova (2014), Sukhoterina (2013)).

The primary and the most important stage in the preparation of the education system to the implementation of the process of inclusion is the stage of psychological and value changes as well as changes of professional competence of specialists (Mukhopadhyay (2014)).

Even in the early stages of inclusive education development there sharply appears the problem of unpreparedness (professional, psychological and methodological) of teachers to work with students with special educational needs; a lack of professional competence of teachers to work in an inclusive environment is present along with psychological barriers and occupational stereotypes (Alekhina (2011), Fayzrakhmanova (2014)).

The main psychological "barrier" is the fear of the unknown, fear of inclusion harm for the other participants in the process, negative attitude and prejudice, professional uncertainty of a teacher, unwillingness to change, psychological unwillingness to work with the "special" children (Sukhoterina (2013), Bartolo (2010)). This poses serious problems not only to the psychological education community, but also to the methodological departments, and most importantly, to the heads of educational institutions implementing the inclusive principles. Kindergarten, school and higher school teachers need specialized integrated assistance from experts in the field of correctional pedagogy, special and educational psychology, to understand and implement approaches to the individualization of students with special educational needs, in the category that, first of all, includes children and students with disabilities. But most importantly, what the teachers have to learn is to work with children with different abilities to study and to take into account this diversity in their pedagogical approach to each.

The state of professional willingness of teachers to work in the conditions of inclusive education is determined by a combination of factors that characterize the different levels and sites of willingness and it is amplified in the case if the teacher himself is an active participant in the learning process and takes the position of the researcher. Criteria of a teacher's willingness to the inclusive teaching practice are the following:

- awareness of the need for innovation activity;

- assurance in the positive results;

- co-ordination of personal goals with innovation activity;

- willingness to overcome failures;

- technical equipment;

- positive assessment of one's own previous experience in the field of inclusive activity;

- the ability for professional reflection;

- equipment with the right knowledge and skills;

- flexibility of thought and behavior, depending on the situation;

- tendency to creativity and anticipation of the desired teaching result at the stage of choosing an influence strategy.

The structure of willingness can be represented by the following interrelated components:

- motivational component, which expresses the conscious attitude of the teacher to the necessity and conditions of inclusive education; it indicates the formed quality of the personality, which is reflected in the interest to the activity, the wish to 
succeed; it shows willingness of a professional to update and ensure the necessary conditions for training in a given mode and successfully complete the task;

- cognitive component integrates and captures the knowledge of the essence of inclusive education, variants of its implementing (research, problemsearching, creative, design), educational facilities, providing organization in the studying process and in extracurricular activities (methodology and technique of teaching);

- -operational-activity component is based on the totality of the developed skills in organizing studying activities within the framework of inclusive education, holding experience activities which ensure the necessary activities in a variety of standard and non-standard situations of educational practice; value-meaningful component fixes the attitude of a teacher to the process, content and results of the professional activities, carried out in different types of teaching, reflects the personal significance of the carried out activities (Slastenin (2002), Hitryuk (2013)).

The integrating link of these components is the emotional-volitional self-regulation, understood as a person's ability to respond adequately to the situation and adjust the performance of professional activities. This is the sense of professional and social responsibility, assurance in success, enthusiasm, selfcontrol and force mobilization, focusing on the task, overcoming fear and doubt of the unknown.

The purposeful formation of a teacher's willingness of inclusive practice creates conditions for the development of a human positive value and meaningful basis for professional activity implementation (Alquraini (2012), Akhmetzyanova (2014)).

Thus, in conditions of inclusive practice the changes must relate all components of professional willingness of teachers. These changes, along with the already existing knowledge should include:
- awareness and acceptance of the idea of inclusive education;

- acquisition of knowledge in the field of special psychology and correctional pedagogy, allowing to solve effectively professional problems in terms of educational integration.

- the data obtained can determine the priorities in teachers training, including:

- - professional development of teachers in special psychology, correctional pedagogy and inclusive education;

- - methodological support for teachers, including the set of scientificmethodological and organizationalmethodological basis of the training organization of persons with disabilities, the design and testing of education models for persons with disabilities, the development of psycho-pedagogical educational technologies, effective in terms of inclusive practices;

- - medical, social and psychological support of the teacher in the process of inclusive education implementation for persons with disabilities with the purpose of a comprehensive analysis of professional experience, to overcome negative emotional phenomena related to professional activity, search and implementation of the resources for personal and professional development.

In this regard, the actual education practice feels the need for professional teachers, able to work with different categories of persons in accordance with various nosologies. There is a need to develop special education of a new type - inclusive education, which enables persons with disabilities to be integrated into the education system at all the levels of education (pre-school, school, professional) and to participate fully in life.

Professional competence is a core indicator of the modern professional qualification. A competent person must not only understand the essence of the problem, but to be able to solve it in virtually any non-standard conditions. 


\section{ACKNOWLEDGMENTS}

The work is performed according to the Russian Government Program of Competitive Growth of Kazan Federal University.

\section{REFERENCES}

Ainscow, M. (2002). Understanding the Development of Inclusive Schools. Taylor \& Francis Group.

Armstrong, F. (2003). Spaced Out: Policy, Difference and the Challenge of Inclusive Education', Springer.

Alekhina, S. V. (2013). Teaching staff training for inclusive education, Pedagogical Journal, 44 (1), 26-32.

Alekhina, S.V., Alekseeva, M.N., Agafona, E.L. (2011). Gotovnost' pedagogov kak osnovnoj faktor uspeshnosti inkljuzivnogo processa $\mathrm{v}$ obrazovanii. Psihologicheskaja nauka i obrazovanie №1: Inkljuzivnyj podhod i soprovozhdenie sem'i v sovremennom obrazovanii.- M., 83-92.

Akhmetzyanova, A.I. (2014). Organization of inclusive education for persons with special needs in Kazan federal University. Journal Education and self-development, 2, 4043.

Akhmetzyanova, A.I. (2014). Podgotovka pedagogicheskih kadrov dlja realizacii inkljuzivnogo obrazovanija invalidov i lic s ogranichennymi vozmozhnostjami zdorov'ja $v$ Kazanskom federal'nom universitete. Inkljuzivnoe obrazovanie - dostupnoe obrazovanie - bezbar'ernaja sreda: materialy vtoroj mezhdunarodnoj nauchno-prakticheskoj konferencii. - Jakutsk: Izdatel'skij dom SVFU, 227-231.

Alquraini, T. A. (2012). Factors related to teachers' attitudes towards the inclusive education of students with severe intellectual disabilities in Riyadh, Saudi. Journal of Research in Special Educational Needs, Volume 12HYPERLINK

"http://onlinelibrary.wiley.com/doi/10.1111/jrse.2012.12.iss ue-3/issuetoc",HYPERLINK

"http://onlinelibrary.wiley.com/doi/10.1111/jrse.2012.12.iss ue-3/issuetoc" HYPERLINK

"http://onlinelibrary.wiley.com/doi/10.1111/jrse.2012.12.iss ue-3/issuetoc"Issue 3HYPERLINK

"http://onlinelibrary.wiley.com/doi/10.1111/jrse.2012.12.iss ue-3/issuetoc",HYPERLINK

"http://onlinelibrary.wiley.com/doi/10.1111/jrse.2012.12.iss ue-3/issuetoc" 170-182.

Bartolo, P. A. (2010). The process of teacher education for inclusion: the Maltese experience. Journal of Research in Special Educational Needs, Special Issue: Preparing teachers for inclusive education, 10, 139-148.

Denisova, O.A. (2012). Strategija i taktika podgotovki pedagogov inkljuzivnogo obrazovanija. Defektologija, 3, 81-89.

Il'ina, N.F. (2014). Stanovlenie innovacionnoj kompetentnosti pedagoga: voprosy teorii i praktiki: monografija. Krasnojarsk, $224 \mathrm{~s}$.

Fajzrahmanova, A.T. (2014). On organization of the inclusive educational environment in higher educational institutions of the Russian Federation. Life Sci J ;11(11s), 59-62.
Gordon, J-S. (2014). Is Inclusive Education a Human Right? The Journal of Law, Medicine \& Ethics, Special Issue: SYMPOSIUM: Human Rights and Disability, Volume 41HYPERLINK "http://onlinelibrary.wiley.com/doi/10.1111/jlme.2013.41.is sue-4/issuetoc"(HYPERLINK

"http://onlinelibrary.wiley.com/doi/10.1111/jlme.2013.41.is sue-4/issuetoc"4HYPERLINK

"http://onlinelibrary.wiley.com/doi/10.1111/jlme.2013.41.is sue-4/issuetoc"), 754-767.

Hoffman, Elin M. (2011). Relationships between inclusion teachers and their students: Perspectives from a middle school. Dissertation Abstracts International Section A: Humanities and Social Sciences., V. 71.

Hornby, G. (2015). Inclusive special education: development of a new theory for the education of children with special educational needs and disabilities. British Journal of Special Education, 42HYPERLINK "http://onlinelibrary.wiley.com/doi/10.1111/bjsp.2015.42.is sue-3/issuetoc"(HYPERLINK

"http://onlinelibrary.wiley.com/doi/10.1111/bjsp.2015.42.is sue-3/issuetoc"3HYPERLINK

"http://onlinelibrary.wiley.com/doi/10.1111/bjsp.2015.42.is sue-3/issuetoc")HYPERLINK

"http://onlinelibrary.wiley.com/doi/10.1111/bjsp.2015.42.is sue-3/issuetoc", 234-256.

Kirillova, E. A. (2015). Historical and Theoretical Basis of Inclusive Education Development in Russia. Review of European Studies No. 5. URL: httpHYPERLINK "http://dx.doi.org/10.5539/res.v7n5p31"://HYPERLINK "http://dx.doi.org/10.5539/res.v7n5p31"dxHYPERLINK "http://dx.doi.org/10.5539/res.v7n5p31".HYPERLINK "http://dx.doi.org/10.5539/res.v7n5p31"doiHYPERLINK "http://dx.doi.org/10.5539/res.v7n5p31".HYPERLINK "http://dx.doi.org/10.5539/res.v7n5p31"orgHYPERLINK "http://dx.doi.org/10.5539/res.v7n5p31"/10.5539/HYPERLI NK

"http://dx.doi.org/10.5539/res.v7n5p31"resHYPERLINK "http://dx.doi.org/10.5539/res.v7n5p31".HYPERLINK "http://dx.doi.org/10.5539/res.v7n5p31"vHYPERLINK "http://dx.doi.org/10.5539/res.v7n5p31"7HYPERLINK "http://dx.doi.org/10.5539/res.v7n5p31"nHYPERLINK "http://dx.doi.org/10.5539/res.v7n5p31"5HYPERLINK "http://dx.doi.org/10.5539/res.v7n5p31"pHYPERLINK "http://dx.doi.org/10.5539/res.v7n5p31"31

Koreneva, E. N. \& Kireev, M.N. (2012). Ponjatie «professional'naja gotovnost'» $\mathrm{V}$ nauchnoj literature. Al'manah sovremennoj nauki i obrazovanija: Tambov: $\begin{array}{llll}\text { Gramota, } & 8 & \text { (63), } & \text { 74-76. }\end{array}$ http://www.gramota.net/materials/1/2012/8/25.html

Loreman, T. et al. (2010). Inclusive education: Supporting diversity in the classroom (2nd ed.). London and New York: Routledge.

Nabiullina, R.H. (2015). The principle of humanism - the fundamental principle of inclusive education. Asian Social Science, Review of European Studies, 7(4), 73-76.

Malofeyev, N.N. (2012). Panegyric on inclusion or a Speech in defence of myself. Upbringing and teaching children with impairments. 1: 35-41.

Mukhopadhyay, S. (2014). Botswana primary schools teachers' perception of inclusion of learners with special educational needs. Journal of Research in Special Educational Need, HYPERLINK 
"http://onlinelibrary.wiley.com/doi/10.1111/jrs3.2014.14.is sue-1/issuetoc"14HYPERLINK

"http://onlinelibrary.wiley.com/doi/10.1111/jrs3.2014.14.is sue-1/issuetoc"(HYPERLINK

"http://onlinelibrary.wiley.com/doi/10.1111/jrs3.2014.14.is sue-1/issuetoc"1HYPERLINK

"http://onlinelibrary.wiley.com/doi/10.1111/jrs3.2014.14.is sue-1/issuetoc")HYPERLINK

"http://onlinelibrary.wiley.com/doi/10.1111/jrs3.2014.14.is sue-1/issuetoc",HYPERLINK

"http://onlinelibrary.wiley.com/doi/10.1111/jrs3.2014.14.is sue-1/issuetoc" 33-42.

Naraian, S. (2013). Dis/ability, Agency, and Context: A Differential Consciousness for Doing Inclusive Education. Curriculum Inquiry, 43HYPERLINK "http://onlinelibrary.wiley.com/doi/10.1111/curi.2013.43.is sue-3/issuetoc"(HYPERLINK

"http://onlinelibrary.wiley.com/doi/10.1111/curi.2013.43.is sue-3/issuetoc"3HYPERLINK

"http://onlinelibrary.wiley.com/doi/10.1111/curi.2013.43.is sue-3/issuetoc")HYPERLINK

"http://onlinelibrary.wiley.com/doi/10.1111/curi.2013.43.is sue-3/issuetoc", 360-387.

Nigmatov, Z.G. (2013). Technologies of interactive learning in the system of inclusive education. Collected materials of International scientific conference "Modern problems of secondary and higher professional school didactics", Kazan: "Pechat- Service XXI century", 221226

Pijl, S. J. (2010). Preparing teachers for inclusive education: some reflections from the Netherlands. Journal of Research in Special Education Needs, 10 (1), 197.
Rieser, R. (2013). Teacher Education for Children with Disabilities. Literature Review. For UNICEF REAP Project.

Slastenin, V.A. i dr. (2002). Pedagogika: Ucheb. posobie dlja stud. vyssh. ped. ucheb. zavedenij - M.: Izdatel'skij centr "Akademija", $576 \mathrm{~s}$.

Stepanova, I.Ju. \& Adol'f, V.A. (2009). Professional'naja podgotovka uchitelja $\mathrm{v}$ uslovijah stanovlenija postindustrial'nogo obshhestva: monografija.- Krasnojarsk, $520 \mathrm{~s}$.

Suhoterina, E.S. (2013). Psihologicheskaja gotovnost' budushhih pedagogov $\mathrm{k}$ rabote $\mathrm{s}$ det'mi s ogranichennymi vozmozhnostjami zdorov'ja. Mir nauki, kul'tury, obrazovanija, 43 (6), 241-243.

Hityuk, V.V. (2012). Inkljuzivnaja gotovnost' kak jetap formirovanija kul'tury pedagoga: strukturno-urovnevyj analiz. Vestnik Brjanskogo gosudarstvennogo universiteta, $1,80-84$.

Hitryuk, V. V. (2013). Gotovnost' pedagoga k rabote s «osobym» rebenkom: model' formirovanija cennostej inkljuzivnogo obrazovanija. Vestnik Baltijskogo federal'nogo universiteta im. I. Kanta, 11, 72-79. 